\title{
Content validation to support the monitoring of disclosure of HIV diagnosis in childhood
}

\author{
Validação de conteúdo para subsidiar o acompanhamento da comunicação do diagnóstico de HIV na infância
}

Validación de contenidos para subvencionar el seguimiento de la comunicación del diagnóstico del VIH en la infancia

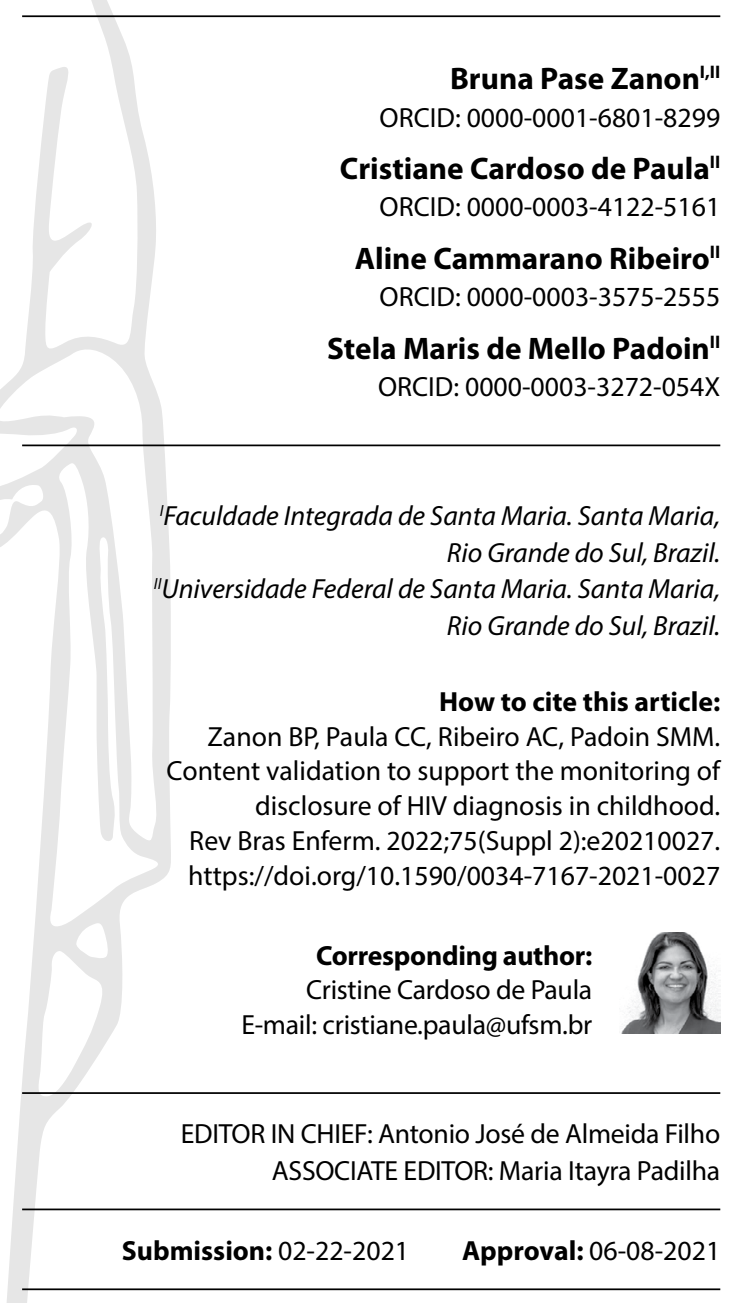

\begin{abstract}
Objectives: to create and validate the content of a guide for monitoring the communication of the HIV diagnosis in childhood. Methods: methodological study, with a design guided by the Knowledge-to-Action (KTA) Framework, supported by a participatory approach. The guide's content was structured according to the communication elements proposed by Lasswel from review studies. Results: the content was validated by 26 experts from nursing, medicine, psychology and pedagogy, using a Likert-type scale for relevance, clarity and precision. Data collection took place online and achieved a Content Validity Index of 0.94. Conclusions: the guide can contribute to the practice of professionals who care for children living with HIV, to support the family in communication and to the child's right to know their diagnosis. For further research, it is recommended to create and validate the face of the technology in order to implement it.

Descriptors: Validation Study; Disclosure; Child Health; HIV; Technology.
\end{abstract}

\section{RESUMO}

Objetivos: criar e validar o conteúdo de um guia para o acompanhamento da comunicação do diagnóstico de HIV na infância. Métodos: estudo do tipo metodológico, com desenho guiado pelo Modelo de Tradução do Conhecimento em Ação, sustentado pela abordagem participativa. O conteúdo do guia foi estruturado segundo os elementos da comunicação propostos por Lasswel a partir de estudos de revisão. Resultados: o conteúdo foi validado por 26 juízes da enfermagem, medicina, psicologia e pedagogia, por escala do tipo Likert para relevância, clareza e precisão. Coleta de dados online, que atingiu o Índice de Validade de Conteúdo de 0,94 . Conclusões: o guia poderá subsidiar a prática dos profissionais que atendem crianças que vivem com HIV, o apoio à família na comunicação e o direito da criança em saber o seu diagnóstico. Para a investigação, recomenda-se criar e validar a face da tecnologia para implementá-la.

Descritores: Estudo de Validação; Comunicação; Saúde da Criança; HIV; Revelação.

\section{RESUMEN}

Objetivos: crear y validar el contenido de una guía para el seguimiento de la comunicación del diagnóstico de VIH en la infancia. Métodos: se trata de un estudio de tipo metodológico, con diseño guiado por el Modelo de Traducción del Conocimiento en Acción y apoyado en el enfoque participativo. El contenido de la guía se estructuró según los elementos de comunicación propuestos por Lasswell a partir de los estudios de revisión. Resultados: el contenido fue validado por 26 jueces de enfermería, medicina, psicología y pedagogía utilizando una escala tipo Likert para la relevancia, la claridad y la precisión. La recogida de datos se llevó a cabo en línea y alcanzó un Índice de Validez de Contenido de 0,94. Conclusiones: la guía puede subvencionar la práctica de los profesionales que asisten a los niños que viven con el VIH, así como apoyar a la familia en la comunicación y garantizar el derecho del niño a conocer su diagnóstico. Para la investigación, se recomienda crear y validar la interfaz de la tecnología para implementarla.

Descriptores: Estudio de Validación; Comunicación; Salud del Niño; VIH; Tecnología. 


\section{INTRODUCTION}

Communicating bad news is understood as the action of revealing true information, even if it may adversely affect people's lives and their conceptions about their future. In the health area, communication is associated with the physical or mental state and can be the knowledge of a diagnosis and/or a difficult prognosis ${ }^{(1)}$.

When the diagnosis is HIV infection in a child, professionals understand that it is challenging to disclose it, especially because it is an incurable disease that carries stigma and often involves the mother's diagnosis and, sometimes, of other family members ${ }^{(2)}$. Professionals are faced with dilemmas that go beyond the clinic, such as feelings of anguish and impotence ${ }^{(3)}$.

The World Health Organization (WHO) points out that pediatric infectology teams and services ${ }^{(4)}$ demand political and government policy support and/or programs to promote HIV disclosure in childhood $^{(5)}$. In Brazil, clinical guidelines mention the procedure of disclosing the HIV diagnosis based on child development and the child's and adolescent's social and clinical conditions ${ }^{(6)}$. Although it contains such elements, they do not provide support for monitoring the communication of the HIV diagnosis to children.

A study with 120 primary caregivers of Nigerian children aged 6 to 17 years old indicated that the disclosure of an HIV diagnosis can foster health benefits for these children ${ }^{(7)}$. A systematic review indicated that full disclosure ranged from $1.7 \%$ to $41.0 \%$, and $49.5 \%$ of children received information that was deflected to explain the illness and health appointments ${ }^{(8)}$. A study with primary caregivers in Zimbabwe showed that $26.9 \%$ of children knew how they were infected and that they could transmit HIV (full disclosure), and the older children were most likely to know their diagnosis ${ }^{(9)}$. A cohort study in rural Zambia indicated that $89.5 \%$ of children were first reported to have partial disclosure at a median age of 7.4 years. Reasons for non-disclosure included caregivers considering the child to be too young, feeling scared or not knowing how to tell the child $^{(10)}$. Furthermore, there is no consensus on who will disclose, whether it will be the parents or the professionals, which implies low disclosure rates in countries such as those in sub-Saharan Africa ${ }^{(5)}$.

Therefore, evidence-based interventions and protocols are needed to support caregivers ${ }^{(8,10)}$. Additionally, there is a lack of national and international evidence about the conduct of the disclosure follow-up. It is suggested that guidelines incorporate aspects of the child's developmental stage, how the diagnosis will be disclosed and the local culture. They should also consider the caregiver's perceptions, which can be barriers to such communication due to the fear of negative reactions and the need for professionals' participation to support the process ${ }^{(8)}$.

\section{OBJECTIVES}

To create and validate the content of a guide for monitoring the disclosure of the HIV diagnosis in childhood.

\section{METHODS}

\section{Ethical aspects}

The research was approved by the Ethics Committee of the Educational Institution, in compliance with the recommendations of Resolution 466/2012.

\section{Design, period and setting}

This is a methodological study. The design was guided by the Knowledge-to-Action (KTA) Framework ${ }^{(11-12)}$, supported by the participatory approach, with engagement between researchers and health professionals who care for children with HIV in the production of a tool to support practice. The framework has a cycle of knowledge creation and a cycle of action. The creation cycle contemplates the knowledge inquiry (first generation), synthesis of knowledge (second generation) and knowledge tool/product (third generation). This study presents the results of the third generation knowledge. Data collection took place from May to June 2020.

\section{Sample: eligibility criteria of professionals for the com- position of the Expert Committee}

The constitution of the population of experts took place by searching a virtual curriculum vitae system (Lattes Platform), created and maintained by the National Council for Scientific and Technological Development, to collect information from researchers, research groups and institutions operating in Brazil. The search was by subject: disclosure of bad news, disclosure of HIV diagnosis, infectology and child health. For eligible participants, a scoring system (maximum of 15) was applied ${ }^{(13)}$, and were defined as experts as those who achieved a minimum of six points (specialization in the area, participation in a project or publication in the subject, and experience of at least one year in the area). For sending the invitation, their region, education, degree and professional performance were considered. Fifty participants were invited to make up the committee of experts, to whom the access link to the questionnaire was sent by email. The snowball technique was also used to expand access to experts, including indications from the International Child Health Nursing Network (RedEnSI) and the Educational Technology Study Network (ETSN), using social media and WhatsApp for the first contact. The feedback of 26 experts was obtained, comprising the final study population.

\section{Study protocol}

For the creation of the guide's content, a path was followed that met the Conceptual Framework, in particular in the creation cycle (Figure 1).

The knowledge inquiry phase (first generation) was developed in a Convergent Care Survey, that had as a result of the discussion with the professionals an Action Plan as a support for the process of disclosing the HIV diagnosis to children ${ }^{(14)}$.

The knowledge synthesis phase (second generation) was developed through two review studies, an integrative one ${ }^{(15)}$ and a scope one ${ }^{(16)}$. The reviews identified evidence in the national and international scientific literature that supports the disclosure of the HIV diagnosis in pediatrics.

The phase that culminates with the knowledge product, which is the focus of this study, included the creation of content for a Care-Educational Technology. This type of technology is based on thinking and doing in people's lives, grounded in care based on scientific knowledge and supported by critical knowledge ${ }^{(17)}$. 
The technology was entitled: "Communication of HIV diagnosis in childhood: guide for professionals who care for children". It is a guiding tool that contains information based on scientific evidence. The guide's content is structured in the elements of the communicative process and offers support (points to be considered in situations experienced by the team of professionals, the family and the child) in monitoring the disclosure of the HIV infection in childhood.
Pediatric Diseases Clinic of the University Hospital, as the creation of the technology emerged from the extension experience in this context $^{(14)}$. For the validation stage, the content of the guide was made available via Google Forms, with a pilot test with 10 doctoral students from the research group who received the access link and tested the operation of the platform, the understanding of the questions and the response time. The necessary adjustments were then made. Afterwards, the access link was sent to the experts by email, along with the informed consent form. The experts assessed the content through a Likert-type scale, with 4 points for "totally adequate", 3 for "adequate", 2 for "partially adequate" and 1 for"inadequate". The content was evaluated for relevance, clarity and accuracy and had space for suggestions.

Second generation: synthesis of scientific evidence from two review studies: an integrative review about the disclosure of bad news in pediatrics ${ }^{(15)}$ and a scope review about the disclosure of the HIV diagnosis in pediatrics ${ }^{(16)}$

Third generation: creating the guide's content - synthesizing and structuring the content according to the elements of the communication framework - discussion of the guide's version with the team of professionals from a specialized pediatric infectology service - evaluation of the guide's content: validation by the experts committee

Source: Adapted from Vieira e Gastaldo ${ }^{(12)}$

Figure 1 - Path for the creating the content of the technology entitled Communication of the HIV diagnosis in childhood: a guide for professionals who care for children, Santa Maria, Rio Grande do Sul, Brazil, 2020

\section{Analysis of results and statistics}

For agreement analysis, the Content Validity Index $(\mathrm{CVI})^{(20)}$ was used, with an assessment made by a group of judges of how much the sample of contents for the guide is representative of the universe of contents on the topic. This index was calculated for each stratum of content in the guide, with a Likert-type scale. The index
It is should be noted that this article presents the creation of the guide's content by the team of researchers and professionals who care for children with HIV in a specialized service in southern Brazil, as well as its validation by experts on the subject. The creation and validation of the guide's face is under development in another study.

The guide's content was structured according to the elements of communication proposed by sociologist Harold Lasswel in the 1940s. Communication is understood as a generating impulse in a receiver and it involves the following elements: the message, as something to convey; the sender, as the one who performs the emission of the message; the receiver, the one who receives it; the channel, which can be language, argumentation, images, gestures, voice, music, among others, for the transmission of the message; the context, understood as situations that occur or must be considered during communication; the effects, repercussions after the transmission of the message; noises, as something that interferes, in particular, in the communication channel, changing the structure of the message; and failures, situations that prevent the communication of the message from happening as expected ${ }^{(18-19)}$.

The synthesized and structured content was submitted to the appreciation of the permanent team of professionals from the score was calculated by the sum of items " 3 " (adequate) and " 4 " (totally adequate). The sum of the CVIs of each block (each communication element) was then performed according to clarity, accuracy and coherence and divided by the total of content excerpts evaluated. This measures the proportion of judges who are in agreement about the content ${ }^{(20)}$. Rates above 0.80 were considered validated. The experts' suggestions were met while maintaining consistency with the guide's objective and in accordance with scientific evidence.

\section{RESULTS}

Twenty-six experts from the Southeast $(n=7)$, South $(n=$ $7)$, North $(n=6)$, Northeast $(n=4)$ and Midwest $(n=2)$ regions of Brazil participated in the content evaluation, and most were female $(n=21)$. Their education was in nursing $(n=21)$, medicine $(n=2)$, psychology $(n=2)$ and pedagogy $(n=1)$. Regarding their degree, there were PhDs $(n=13)$, masters $(n=10)$ and specialists $(n=3)$. They worked in teaching $(n=18)$, research $(n=15)$ and health care $(n=13)$. The averages were age of 40.6 years, time since graduation of 17.3 years, time of professional experience of 15.5 years and time since the highest degree of 7.2 years. 
Based on the review studies, the evidence were organized in each communication element ${ }^{(19)}$. The first session presents the guide, and it aims to show its applicability in care practice and is followed by the other sessions with the following elements: message, manner and communication channel (Figure 2).

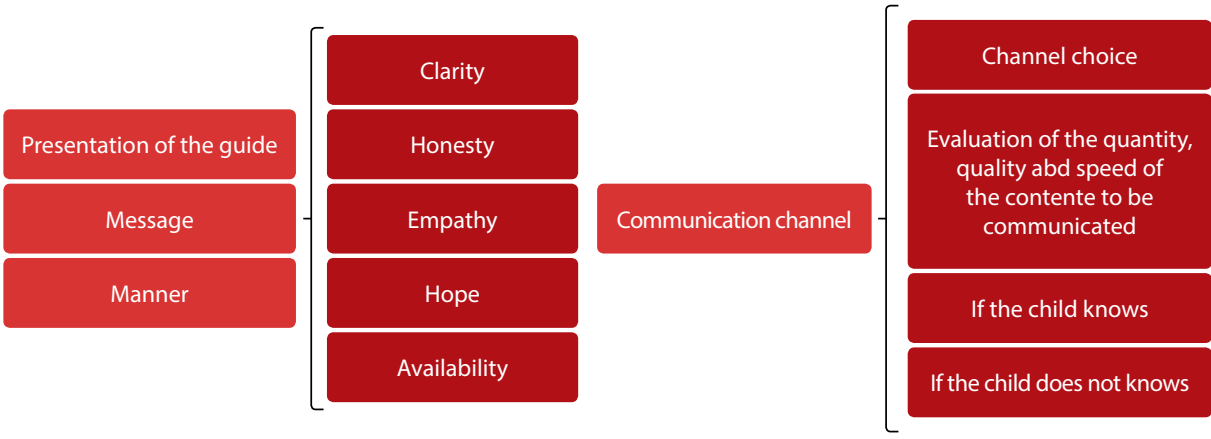

Figure 2 - Presentation and "message","manner" and "communication channel" elements of the guide's content structure, Santa Maria, Rio Grande do Sul, Brazil, 2020

The content of the guide about the "message" element contains information about the child's HIV infection. Recognized as difficult news, the message will be addressed with family members in the communicative process of support and follow-up of the disclosure to the child. The manner of communicating reflects the professional's commitment to avoid incomplete and/or dubious information in order to enhance the understanding of the information by the family. It is indicated that the professional communicates clearly and adopts an honest, empathetic, hopeful and available attitude. In addition, it is important to register the guidelines provided, considering the partial or full disclosure.

In the communication channel, the content of the guide recommends friendliness and exemplifies that the professional can request a feedback on the understanding of the message, mediated by pictures and open questions. The guide instructs professionals to pay attention to the quantity and quality of the content that refers to objectivity and depth of information. Additionally, it informs how professionals can assess the speed of each communication process, considering the family members' preferences and the child's needs.
The "communication context" element (Figure 3) was intended to clarify the situations of professionals, the family and the child, which involve the child's right to know about the diagnosis of HIV infection. These situations need to be considered by the professional.

In the "context" element, the content of the guide refers to the child's right to know their diagnosis. It emphasizes that professionals should ask family members what they understand about the child's right to know about their diagnosis, and then start an approach pointing out the benefits of disclosing the HIV diagnosis. It also recommends discussions among the health team to assess whether other professionals have this understanding.

Regarding the professional context, the guide refers to multidisciplinary work, team organization, training and privacy. In the family's context, the guide prescribes the analysis of situations such as schooling, preparation and support network of that family. Moreover, regarding the child's context, there are indications for the professional to mediate the communicative process: observing questions, curiosities and the child's current stage of development. It is worthy to note that the family should be a source of information, as many questions are made at home. The professionals should therefore discuss the child's schooling and maturity to receive information about the diagnosis.

The content of the element "sender and receiver of the message, effects, noise and failures" (Figure 4) included the family as the main sender, the professionals as supporters in the monitoring of the disclosure to the child, the responses generated and the actions that can interfere with communication.

The content of the guide indicates that when the receiver of the message is the family, the sender will be the professional. When the receiver is the child, the main sender will be the family, with support from the professional(s), as the family is the most suitable to perform the disclosure, due to the close relationship and the ability to identify the opportune moment to disclose.

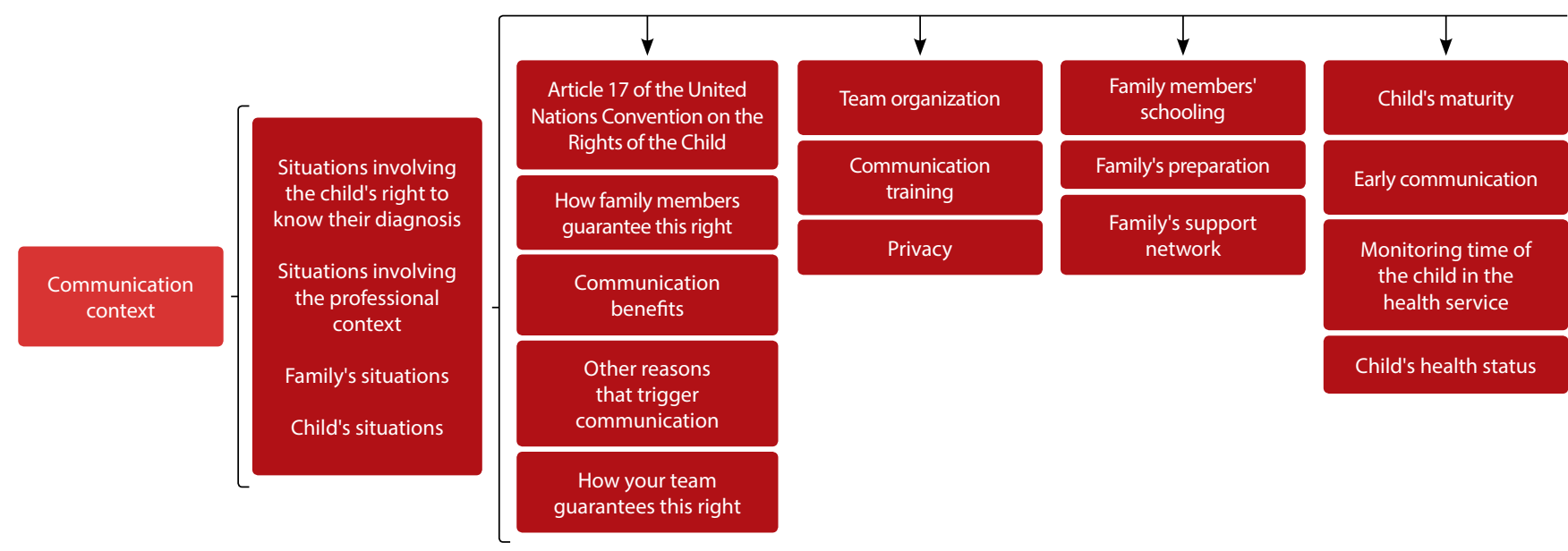

Figure 3 - "Communication context" element of the guide's content structure, Santa Maria, Rio Grande do Sul, Brazil, 2020 


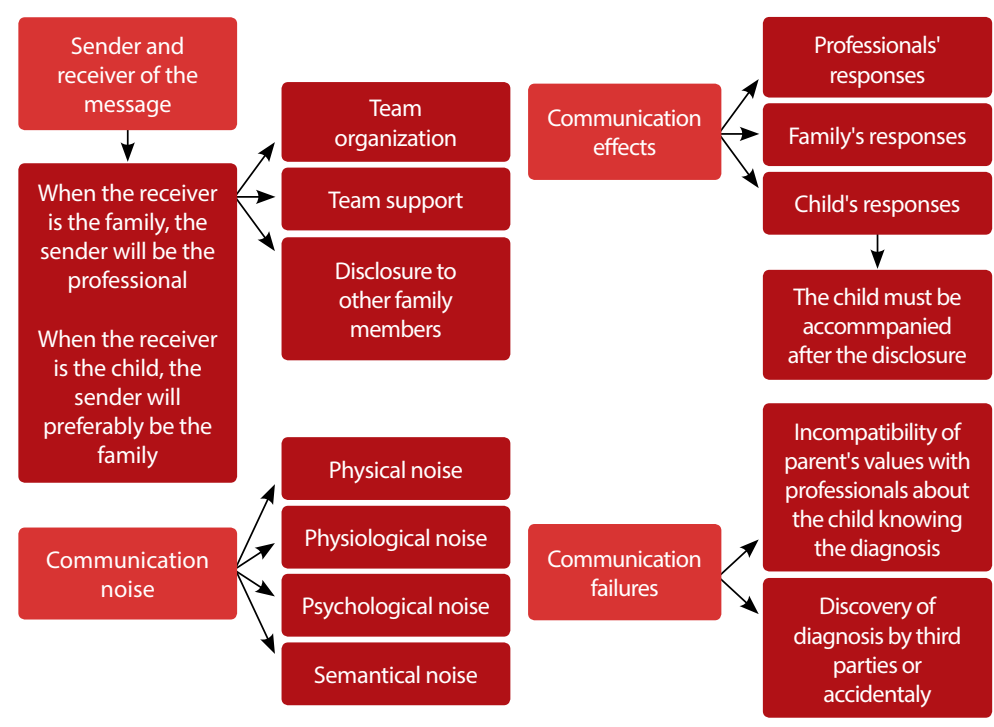

Figure 4 - Element "sender and receiver of the message, effects, noise and failures" of the content structure of the guide, Santa Maria, Rio Grande do Sul, Brazil, 2020
For the qualification of the content, the judges' suggestions were carefully read, and they converged on the content of three of the communication elements: sender (the role of each professional); receiver (limit for children with special situations); and the child's context (maturity). To analyze the relevance of changes, the researchers reassessed scientific evidence for theoretical justification. The content of the "sender" element was reformulated to clarify that the professional's role is to support the family in the communication process with the child, the physician's role is informing the family about the diagnosis of HIV infection and the multidisciplinary team's role is monitoring this communication to the family and the child. Expressions such as "children with intellectual disability" were removed from the content of the "receiver" element, as this is a situation that requires specific skills for monitoring communication and has a lack of scientific evidence and, consequently, a limit for application in the guide. Lastly, the con-
The content of the guide about the "effects" element informs that after the communication the effect will always be present, whether negative or positive. The most present repercussions are associated with negative feelings related to HIV, since it is an infection that carries stigma and prejudice sustained by society. In professionals, the effects are associated with the burden of responsibility for disclosing difficult news, which can be expressed by anxiety in mediating this process and frustration with the limits established by the family. The effects on the family involve the feeling of guilt for the situation, while the effects on the child are milder and soon dissipate.

Concerning the noise, the content exemplifies each type (physical, physiological, psychological and semantic) so that the professional can minimize them in the communicative process. The guide recommends that they perform the disclosure in a quiet and private place, and with a multidisciplinary team sensitized to welcome the feelings aroused, in addition to using a language accessible to receivers.

In the guide, communication failures are exemplified in situations that can prevent the communication from happening, so that the professional can avoid them, for example, the child discovering the diagnosis accidentally or by third parties.

In the judges' evaluation, the guide's objective reached a CVI of 0.92 , its structure 0.89 and its relevance 0.96 . The content of the guide reached an overall CVI of 0.94 (Table 1).

Table 1 - Content validity index of the guide by category analyzed by the experts

\begin{tabular}{|c|c|c|c|c|c|}
\hline \multicolumn{2}{|l|}{ Guide content } & \multirow{2}{*}{$\begin{array}{c}\text { Relevance } \\
0.96\end{array}$} & \multicolumn{2}{|c|}{$\begin{array}{c}\text { CVI } \\
\text { Clarity Accuracy }\end{array}$} & \multirow{2}{*}{$\begin{array}{c}\text { Global } \\
0.88\end{array}$} \\
\hline presentation & & & 0.84 & 0.84 & \\
\hline structure & message & 0.96 & 0.84 & 0.88 & 0.89 \\
\hline according to the & manner & 1.0 & 0.90 & 0.90 & 0.93 \\
\hline elements of the & channel & 0.99 & 0.98 & 0.94 & 0.97 \\
\hline communicative & context & 0.99 & 0.92 & 0.91 & 0.94 \\
\hline process & sender and receiver & 0.97 & 0.91 & 0.92 & 0.93 \\
\hline & effects & 0.98 & 0.95 & 0.95 & 0.90 \\
\hline & noise & 1.0 & 0.97 & 0.97 & 0.98 \\
\hline & failures & 1.0 & 1.0 & 1.0 & $\begin{array}{c}1.0 \\
0.94\end{array}$ \\
\hline
\end{tabular}

tent of the "child's context" element was reformulated, with the inclusion of detailed content for the assessment of cognitive maturity and examples of how to observe children's behaviors, such as questions that indicate their openness and readiness to receive information, as well as developmental milestones, with examples of characteristics of the different stages of childhood.

\section{DISCUSSION}

Scientific evidence were synthesized and structured in the elements of the communicative process to compose the guide's content. This content contains specific items that will allow health professionals to support families in advancing the disclosure of the diagnosis to the child, as previously specified in the figures in this article.

The "message" element includes the child's diagnosis and prognosis ${ }^{(21-24)}$ and what must be addressed in this communicative process, as well as the recognition that it is difficult news ${ }^{(1)}$. This message must be communicated in a clear manner and the professional must speak calmly, with more than one meeting and using accessible language ${ }^{(25)}$. Evidence support that an honest manner demands that the professional have prudent sincerity and answers questions, without omitting or softening the truth ${ }^{(6)}$. An empathetic posture demands that the professional be available to listen to the fears and anxieties triggered after the diagnosis is disclosed ${ }^{(26)}$. In addition, it is important to establish a hopeful attitude, inspiring confidence in future treatment, combined with a welcoming perspective of remaining available for family members when they have questions ${ }^{(27)}$. If the child is suspicious of their diagnosis, it is recommended that the professional indicate the family to start the communication ${ }^{(28-29)}$.

The use of recreational activities, such as toys, children's books and games, is indicated as a communication channel. These resources can help children talk about difficult issues ${ }^{(30)}$, such as the HIV diagnosis. It is important to pay attention to the quantity and quality of the content communicated, considering the family's preference that communication take place gradually. 
The content communicated increases according to the child's maturity and stage of development, with details according to who is receiving the information, the family history, health and emotional conditions, and education ${ }^{(28)}$.

The context surrounding the child's right to know about their diagnosis is ensured in official documents that recommend that they receive information about their clinical condition and treatment, respecting their level of understanding ${ }^{(31)}$. Family members as well as professionals must guarantee this right and be clear about the benefits ${ }^{(7)}$ for the child to know their diagnosis, such as: adherence to treatment, encouragement for self-care and future safe sexual behavior. It is essential to prevent them from reaching adolescence without knowing the diagnosis ${ }^{(2)}$. Sometimes professionals have difficulty understanding, protecting, promoting and/or supporting this right, which is often due to fear of not knowing how to conduct the communication and to the resistance of the family.

In the professional context, the health service must offer working conditions to achieve an adequate organization, since each area has a particular perception regarding communication ${ }^{(32)}$. It should also provide moments of discussion, training courses for the team and a private place for communication ${ }^{(32-33)}$.

In the context of the family, schooling is a determining factor in the search for information about HIV(34), as well as the family's preparation to receive the diagnosis and the support network they have ${ }^{(35)}$. The family may not want to disclose the diagnosis, due to insecurity about the child's reaction regarding the transmission of the disease and, mainly, for hiding the diagnosis for so long, with an overload of prejudice and stereotypes. However, this fear needs to be overcome by the understanding that the child has the right to know their status ${ }^{(2)}$.

In the child's context, the preschool phase enables communication with information centered on care. These information progressively lead to the complete disclosure of the diagnosis, preferably in the school phase. How long the child attends the service can be a determining factor for disclosure to take place smoothly, contributing to their well-being and that of their family. As the time in contact with the health service is longer, the outcome will be a greater bond with the professionals, favoring the relationship and the communication process ${ }^{(36)}$. In addition, the child's health status may influence the decision; therefore, situations of hospitalization and worsening of the disease are indicative of postponing the disclosure ${ }^{(37)}$.

Regarding the sender-receiver, it is up to the professional to establish the first contact between the child and the family, answering questions that may arise following the HIV diagnosis and preparing the family for the communication with the child. It is recommended that communication be carried out by the professional who has a stronger bond with the family, and a multidisciplinary team should also be involved in this communicative process ${ }^{(14)}$. The family demands support from professionals, which implies the need for the presence of a professional when answering the child's questions, which may arise regarding the clinical condition of the infection ${ }^{(8,22)}$. As for sharing the diagnosis with relatives, evidence show that the family prefers to be told the bad news in the presence of other family members, so that they have emotional support during this process ${ }^{(38-39)}$. In addition, it is the family members who will deal with the child's feelings, being able to comfort and support them ${ }^{(40)}$. The intention of those who will communicate the message to the child must be guided by the premise of promoting their well-being, minimizing risks and strengthening the relationship between family and child ${ }^{(4)}$.

In professionals, the effects of the communicative process can be expressed by anxiety, crying, feelings of exhaustion and sadness ${ }^{(3)}$. The effects on the family are related to the feeling of guilt for transmitting the virus to the child and for the suffering they may cause in the child with the disclosure of the HIV diagnosis ${ }^{(28)}$. The child, at the time of disclosure, shows negative feelings, but soon these feelings are absorbed ${ }^{(41)}$.

The professionals can provide a space for the child to express their feelings, putting themselves in a position to understand and question their concerns arising from the disclosure of the diagnosis ${ }^{(36)}$. After communicating the message, professionals must monitor the children and their families to analyze whether there have been changes in the child's behavior and perform care according to the demands of the child and that of their family ${ }^{(36)}$.

Communication may also involve noise interference. Physical noises are represented by sounds that make it difficult for the sender and receiver to listen and concentrate ${ }^{(25)}$; physiological ones are health conditions of the receiver that can negatively interfere with communication ${ }^{(36)}$; psychological ones are represented by feelings of uncontrollable crying and sadness not welcomed by the sender; and the most frequent are the semantic noises, identified by the use of a scientific language that makes it difficult for the receiver to understand ${ }^{(25)}$.

Communication failures arise from incompatibility of parents values that prevent disclosure. This situation is generated by insecurity and fear that the child will suffer prejudice, be unable to deal with the diagnosis and have emotional consequences ${ }^{(42)}$. Additionally, the child and family may discover the HIV diagnosis accidentally or by third parties, who are people that are not present in their daily environment, which causes a failure and arouses negative reactions to the message ${ }^{(43)}$.

\section{Study limitations}

A limit of this study is related to the linearity of the conceptual framework of communication. Another limit in the preparation of the content of this guide is the lack of evidence of variables that impact giving and reacting to news from comparative and follow-up studies. The research group committed itself to returning to the guide's target population to establish the type of technology, then create the face guided by interactive and procedural communicative frameworks, and assess its usability. These are examples of the possibility of conducting intervention studies.

\section{Contributions to the area}

Nursing is strengthened as a science by producing a careeducational technology with due methodological rigor, structured according to a theoretical communication framework and evaluated by specialists in the field. Considering that the guide's content was based on national and international scientific evidence, it can be applied in other countries, as long as it 
is translated and adapted to the local context, as recommended by the knowledge-to-action framework.

Content creation and validation contributed to the introduction of a technological innovation in the work process of professionals in the area. As a guiding tool, the guide will offer information structured on the elements of communication: what is the message to be communicated, how to communicate, by whom/to whom, through which channels and in which contexts (professional, family and child); all of this needs to be considered in order to minimize negative effects, noise and failures in the communication process. Thus, the professional can seek information for decision-making according to the demand of their care practice in one or more of these elements, considering their expertise, service conditions and user preferences in communication with the family and in support for it to take an active role in communicating to the child.

\section{CONCLUSIONS}

The content of the guide for disclosing the diagnosis of HIV infection by professionals who care for children was validated with an overall CVI of 0.94 , which means that the guide has theoretical support to contribute to the practice of professionals who care for children living with HIV. The professional, in a multidisciplinary team, will support the family in disclosing the diagnosis to the child, in an honest, empathetic, objective and hopeful manner, available for continuity and in a private space. We emphasize the importance of professionals and families listening to the child, paying attention to the particularity of their clinical and life contexts and assessing their demands and needs, as well as their current developmental stage. We understand that there needs to be a consensus between professionals and family, and that services must recognize the child's right to know their diagnosis and warn the family about how important it is for their full well-being. For co-responsibility to be effective between the family that communicates and the professional who supports the monitoring of this process, it is necessary that the service management subsidize the conditions of organization of the multidisciplinary team, training and privacy. For further research, the recommendation is to create and validate the face of the technology in order to implement it.

\section{ACKNOWLEDGMENT}

We would like to thank Juliana Facco Segalla for producing the article's images and the research participants who acted as judges with their expertise on the subject, which culminated in the validation of the guide.

\section{SUPPLEMENTARY MATERIAL}

Zanon BP. Comunicação do diagnóstico de HIV: tradução do conhecimento e avaliação do conteúdo de um guia para profissionais que atendem crianças. [tese]. Santa Maria (RS): Programa de Pós-Graduação em Enfermagem, Universidade Federal de Santa Maria; 2020. Available in: https://repositorio.ufsm.br/bitstream/ handle/1/20484/TES_PPGENFERMAGEM_2020_ZANON_BRUNA. pdf? sequence=1\&isAllowed=y

\section{REFERENCES}

1. Singh MM, Agarwal RK. Breaking bad news in clinical setting: a systematic review. Indian J Appl Res. 2017;7(12):29-32. https://doi. org/10.36106/ijar

2. Gachanja G, Burkholder GJ. A model for HIV disclosure of a parent's and/or a child's illness. PeerJ. 2016;4:e1662. https://doi.org/10.7717/ peerj.1662

3. Johnson J, Panagioti M. Interventions to improve the breaking of bad or difficult news by physicians, medical students, and interns/ residents: a systematic review and meta-analysis. Acad Med. 2018;93(9):1400-12. https://doi.org/10.1097/ACM.0000000000002308

4. World Health Organization. Guideline on HIV disclosure counselling for children up to 12 years of age. Geneva: WHO; 2011 [cited 2020 Nov 15]. Available from: https://www.who.int/hiv/pub/hiv_disclosure/en/

5. Odiachi A. The impact of disclosure on health and related outcomes in human immunodeficiency virus-infected children: a literature review. Front Public Health. 2017;5:231. https://doi.org/10.3389/fpubh.2017.00231

6. Ministério da Saúde (BR). Protocolo clínico e diretrizes terapêuticas para manejo da infecção pelo HIV em crianças e adolescentes. Brasília, DF: MS; 2018[cited 2020 Nov 15]. Available from: http://www.aids.gov.br/pt-br/pub/2017/ protocolo-clinico-e-diretrizes-terapeuticas-para-manejo-da-infeccao-pelo-hiv-em-criancas-e

7. Wariri O, Ajani A, Raymond MP, lliya A, Lukman O, Okpo E, Isaac E. "What will my child think of me if he hears I gave him HIV?": a sequential, explanatory, mixed-methods approach on the predictors and experience of caregivers on disclosure of HIV status to infected children in Gombe, Northeast Nigeria. BMC Public Health. 2020;20(1):373. https://doi.org/10.1186/s12889-020-08506-x

8. Britto C, Mehta K, Thomas R, Shet A. Prevalence and correlates of HIV disclosure among children and adolescents in low- and middleincome countries: a systematic review. J Dev Behav Pediatr. 2016;37(6):496-505. https://doi.org/10.1097/DBP.0000000000000303

9. Finnegan A, Langhaug L, Schenk K, Puffer ES, Rusakaniko S, Choi Y, et al. The prevalence and process of pediatric HIV disclosure: A population-based prospective cohort study in Zimbabwe. PLoS One. 2019; 14(5):e0215659. https://doi.org/10.1371/journal.pone.0215659

10. Sutcliffe CG, Drogt CS, Van Dijk JH, Hamangaba F, Muleka M, Munsanje B, et al. Timing of and factors associated with HIV disclosure among perinatally infected children in rural Zambia.AIDS. 2020;34(4):579-88. https://doi.org/10.1097/QAD.0000000000002411

11. Graham ID, Straus SE, Tetroe J. Knowledge translation in health care: moving from evidence to practice. 2a ed. [Oxford:Willey-Blackwell]; 2013. 
12. Vieira ACG, Gastaldo DHD, Harrison D. Como traduzir o conhecimento científico à prática?: conceitos, modelos e aplicação. Rev Bras Enferm. 2020;73(5):e20190179. doi: https://doi.org/10.1590/0034-7167-2019-0179

13. Fehring RJ. The Fehring model. In: Carroll-Johnson RM, Paquette CJ, editors. Classification of nursing diagnosis: proceedings of the tenth conference. Philadelphia: Lippincott; 1994. p. 55-57.

14. Zanon BP, Paula CC, Padoin SMM. Revealing an HIV diagnosis for children and adolescents: subsidy for the practice of care. Rev Gaucha Enferm. 2016;37(spe):e20160040. https://doi.org/10.1590/1983-1447.2016.esp.2016-0040

15. Zanon BP, Cremonese L, Ribeiro AC, Padoin SMM, Paula CC. Communication of bad news in pediatrics: integrative review. Rev Bras Enferm. 2020;73(suppl 4):e20190059. https://doi.org/10.1590/0034-7167-2019-0059

16. Cremonese, L. Comunicação do diagnóstico de infecção pelo HIV em pediatria: revisão de escopo [tese]. Programa de Pós-Graduação em Enfermagem, Universidade Federal de Santa Maria. Santa Maria; 2020.

17. Salbego C, Nietsche EA, Teixeira E, Girardon-Perlini NMO, Wild CF, Ilha S. Care-educational technologies: an emerging concept of the praxis of nurses in a hospital context. Rev Bras Enferm. 2018; 71(suppl 6):2666-74. https://doi.org/10.1590/0034-7167-2017-0753

18. Lasswell HD. Communications research and public policy. Public Opin Q. 1972;36(3):301-10. https://doi.org/10.1086/268012

19. Lasswell HD. The structure and function of communication in society [Internet]. In: Iletişim kuram ve araştırma dergisi Sayı Kış-Bahar. 2007[cited 2020 Nov 15]. p.215-228 Available from: https://pracownik.kul.pl/files/37108/public/Lasswell.pdf

20. Alexandre NMC, Coluci MZO. Validade de conteúdo nos processos de construção e adaptação de instrumentos de medidas. Cienc Saude Colet. 2011;16(7):3061-8 https://doi.org/10.1590/S1413-81232011000800006

21. Baker AN, Bayer AM, Kolevic L, Najarro L, Viani RM, Deville JG. Child, caregiver, and health care provider perspectives and experiences regarding disclosure of HIV status to perinatally infected children in Lima, Peru. J Int Assoc Provid AIDS Care. 2018;17:2325957417752257. https://doi.org/10.1177/2325957417752257

22. Nzota MS, Matovu JKB, Draper HR, Kisa R, Kiwanuka SN. Determinants and processes of HIV status disclosure to HIV-infected children aged 4 to 17 years receiving HIV care services at Baylor college of medicine children's foundation Tanzania, centre of excellence (COE) in Mbeya: a cross-sectional study. BMC Pediatr. 2015;15:81. https://doi.org/10.1186/s12887-015-0399-3

23. Jalmsell L, Lövgren M, Kreicbergs $\mathrm{U}$, Henter Jl, Frost B-M. Children with cancer share their views: tell the truth but leave room for hope. Acta Paediatr. 2016;105(9):1094-9. https://doi.org/10.1111/apa.13496

24. Ekstrand ML, Heylen E, Mehta K, Sanjeeva AS, Shet A. Disclosure of HIV status to infected children in South India: perspectives of caregivers. J Trop Pediatr. 2018;64(4):342-7. https://doi.org/10.1093/tropej/fmx079

25. Namukwaya S, Paparini S, Seeley J, Bernays S. "How do we start? and how will they react?": disclosing to young people with perinatally acquired HIV in Uganda. Front Public Health. 2017;5:343. https://doi.org/10.3389/fpubh.2017.00343

26. Lima KMA, Maia AHN, Nascimento IRC. Communication of bad news in palliative care within pediatric oncology. Rev Bioet. 2019;27(4):71927. https://doi.org/10.1590/1983-80422019274355

27. Oliveira-Cardoso ÉA, Garcia JT, Santos LL, Santos MA. Comunicando más notícias em um hospital geral: a perspectiva do paciente. Rev SPAGESP [Internet]. 2018[cited 2021 Jan 5];19(1):90-102. Available from: http://pepsic.bvsalud.org/scielo. php?script=sci_arttext\&pid=S1677-29702018000100008\&lng=pt\&nrm=iso

28. Afonso SBC, Minayo MCS. Relações entre oncohematopediatras, mães e crianças na comunicação de notícias difíceis. Cienc Saude Colet. 2017;22(1):53-62. https://doi.org/10.1590/1413-81232017221.14592016

29. Elizabeth Glaser Pediatric AIDS Fundation. Kit de ferramentas para revelação do estado de HIV a populações pediátrica e adolescentes [Internet]. Washington, DC: EGPZF; 2018[cited 2021 Jan 07]. Available from: https://www.pedaids.org/wp-content/uploads/2019/01/NewHorizons_HIV-Status-Disclosure-Toolkit_Port.pdf

30. Wright S, Amzel A, Ikoro A, Srivasta M, Leclerc-Madlala S, Bowsky S, et al. Talking to children about their HIV status: a review of available resources, tools, and models for improving and promoting pediatric disclosure. AIDS Care. 2017;29(8):1019-25. https://doi.org/10.1080/095 40121.2016.1273471

31. Amador DD, Rodrigues LA, Mandetta MA. É melhor contar do que esconder": a informação como um direito da criança com câncer. Rev Soc Bras Enferm Ped. 2016;16(1):28-35. https://doi.org/10.31508/1676-3793201600004

32. Kalembo FW, Kendall GE, Ali M, Chimwaza AF. Socio-demographic, clinical, and psychosocial factors associated with primary caregivers' decisions regarding HIV disclosure to their child aged between 6 and 12 years living with HIV in Malawi. PLoS One. 2019;14(1):e0210781. https://doi.org/10.1371/journal.pone.0210781

33. Sariah A, Rugemalila J, Somba M, Minja A, Makuchilo M, Tarimo E, et al. “Experiences with disclosure of HIV-positive status to the infected child": perspectives of healthcare providers in Dar es Salaam, Tanzania. BMC Public Health. 2016;16(1):1083. https://doi.org/10.1186/ s12889-016-3749-7

34. Paintsil E, Kyriakides CT, Antwi S, Renner L, Nichols JS, Amissah K, et al. Clinic-based pediatric disclosure intervention trial improves pediatric HIV status disclosure in Ghana. J Acquir Immune Defic Syndr. 2020;84(1):122-31. https://doi.org/10.1097/QAI.0000000000002316

35. Kodyalamoole NK, Badiger S, Kiran NU, Dodderi SK, Rewari BB. Pattern of paediatric HIV status disclosure in coastal Karnataka. Indian J Med Res. 2018;47(5):501-6. https://doi.org/10.4103/ijmr.IJMR_1821_15 
36. Boon-Yasidhi V, Chokephaibulkit K, McConnell M, Angsukiattitavorn S, Klumthanom K. Pediatric HIV disclosure manual. Thailand: Ministry of Public Health; 2010[cited 2020 Nov 15]. Available from: http://www.cqihiv.com/Final_Pediatric_HIV_Eng.pdf

37. Appiah SCY, Kroidl I, Hoelscher M, Ivanova O, Dapaah JM. A Phenomenological account of HIV disclosure experiences of children and adolescents from northern and southern Ghana. Int J Environ Res Public Health. 2019;16(4):595. https://doi.org/10.3390/ijerph16040595

38. Aein F, Delaram M. Giving bad news: a qualitative research exploration. Iran Red Crescent Med J. 2014;16(6):e8197. https://doi.org/10.5812/ ircmj.8197

39. Zhang Y, Li X, Qiao S, Yang X, Zhou Y, Shen Z. Perceived benefits and costs of disclosing HIV diagnosis to family members among people living with HIV in Southern China: an application of a decision-making framework. AIDS Care. 2021;33(3):403-407. https://doi.org/10.1080/0 9540121.2020 .1728217

40. Madiba S, Mokgatle M. Health care workers' perspectives about disclosure to HIV-infected children; cross-sectional survey of health facilities in Gauteng and Mpumalanga provinces, South Africa. PeerJ. 2015;3:e893. https://doi.org/10.7717/peerj.893

41. Phuma-Ngaiyaye EE, Dartey AF. Experiences of children living with HIV and AIDS following their diagnosis disclosure in Mzuzu, Malawi. Vulnerable Child Youth Stud. 2015;10(4):357-65. https://doi.org/10.1080/17450128.2015.1083639

42. Ubesie AC, Iloh KK, Emodi IJ, Ibeziako NS, Obumneme-Anyim IN, Iloh ON, et al. HIV status disclosure rate and reasons for non-disclosure among infected children and adolescents in Enugu, Southeast Nigeria. SAHARA J. 2016;13(1):136-41. https://doi.org/10.1080/17290376.201 6.1226942

43. Farthing $\mathrm{H}$, Reynolds NR, Antwi S, Alhassan A, Ofori IP, Renner L, et al. Illness narratives of children living with HIV who do not know their HIV Status in Ghana: i'm sick, but i don't know the sickness-a qualitative study. AIDS Behav. 2020;24(11):3225-31. https://doi.org/10.1007/ s10461-020-02884-4 